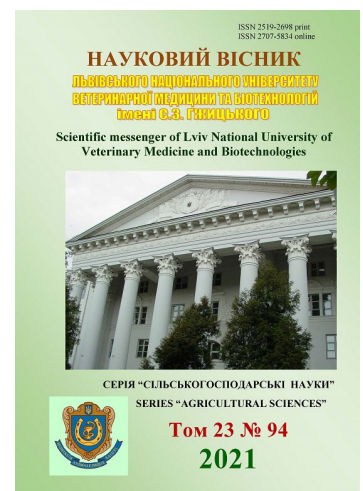

Науковий вісник Дьвівського національного університету ветеринарної медицини та біотехнодогій імені С.3. Гжицыкого. Серія: Сільськогосподарські науки

\section{Scientific Messenger of Lviv National University of Veterinary Medicine and Biotechnologies. Series: Agricultural sciences}

https://nvlvet.com.ua/index.php/agriculture

UDC 636.4.082/57.087.01

\title{
Analysis of the stillborn piglet's distribution in the Large White sows
}

\author{
A. S. Kramarenko, S. S. Kramarenko, S. I. Lugovoy \\ Mykolayiv National Agrarian University, Mykolayiv, Ukraine
}

Article info

Received 25.01.2021

Received in revised form 25.02.2021

Accepted 26.02.2021

Mykolayiv National Agrarian University, 9, Georgiya Gongadze Str., Mykolayiv, 54020, Ukraine. Tel: +38-050-991-53-14

E-mail: kssnail0108@gmail.com
Kramarenko, A. S., Kramarenko, S. S., \& Lugovoy, S. I. (2021). Analysis of the stillborn piglet's distribution in the Large White sows. Scientific Messenger of Lviv National University of Veterinary Medicine and Biotechnologies. Series: Agricultural sciences, 23(94), 25-30. doi: $10.32718 /$ nvlvet-a 9405

The main aim of this paper was to estimate the piglet stillbirth incidence distribution in the Large White $(L W)$ sows. The population used for the present study is from a pig farm managed by the Limited Liability Company (LLC) "Tavriys'ki svyni" located in Skadovsky district (Kherson region, Ukraine). The experimental materials used for this study consisted of 100 inds. of productive parent sows of the Large White breed. The estimation of reproductive performance was conducted for each animal included in this study. The total number of piglets born (TNB), number of stillborn piglets (NSB) and frequency of stillborn piglets (FSB) per litter were monitored in the first eight parities in the period of eleven years (2007-2017). The 800 farrowings averaged 11.3 piglets per litter. Of the 9037 piglets born, 7895 were live born and 1142 were stillborn. Stillborn pigs were observed in $63.3 \pm 1.7 \%$ of the litters and the pig stillbirth incidence was $12.6 \pm 0.4 \%$. The percentage of pigs born dead in total pigs born, obtained in this study is within the range of rates (5 to $15 \%$ ) reported for commercial pig farms in other countries. The frequencies of litters with 1 , 2, 3, 4 and 5 or more stillborn piglets were 27.1, 14.8, 10.6, 5.8 and 5.0\%, respectively. The frequency of litters with at least one stillborn piglet varied from $44 \%$ (2nd parity) to $76 \%$ (6th parity). Significant factor in the analysis for frequency of litters with at least one stillborn piglet was parity number in sow (Chisquared test: $\left.\chi^{2}=51.35 ; d f=7 ; P<0.001\right)$. This frequency increased as parity number in sow increased (Pearson correlation coefficient: $r=0.929 ; P<0.01$ ). We noted that the piglet stillbirth incidence in the $L W$ sow's litter took place already during the first farrowing for almost half of the sows (46\%). In general, this distribution is well approximated by the exponential model equation $(y=73.567 * \exp (-0.551 x)$; $\left.R^{2}=97.09 \%\right)$. The LW sows with stillborn piglets in four out of eight farrowings were the most reported. The value of the entropy of the traits NSB and FSB varied significantly among sows of different parities (Chi-squared test: in both cases $P<0.001)$. At the same time, a significant increase in the entropy estimates for both traits from the $1^{\text {st }}$ parity to the 8th parity was noted (Spearman's rank correlation: $P<0.001 \ldots 0.002)$.

Key words: stillborn piglets, sows, parity number, entropy, the Large White breed pig.

\section{Аналіз розподілу мертвонароджених поросят у свиноматок великої білої породи}

\author{
О. С. Крамаренко, С. С. Крамаренко, С. І. Луговий
}

Миколаївський національний аграрний університет, м. Миколаїв, Україна

Основною метою даної роботи було оцінити розподіл мертвонароджених поросят серед свиноматок великої білої породи (ВБП). Тварини, яких було використано для иього дослідження, утримувалися на свинофермі ТОВ «Таврійські свині», розташованій у Скадовському районі (Херсонська область, Україна). Для дослідження використовувалися експериментальні матеріали для 100 особин основного стада свиноматок ВБП. Оиінювали відтворювальні ознаки кожної тварини, включеної в ие дослідження, а саме: загальну кількість поросят при народженні (TNB), кількість мертвонароджених поросят (NSB) та частку мертвонароджених поросят (FSB) у гнізді для перших восьми опоросів протягом одинадияти років (2007-2017). У середньому за даними 800 опоросів 
було зафіксовано 11,3 поросят на гніздо. 39037 народжених поросят 7895 були живонародженими та 1142 мертвонародженими. Мертвонароджені поросята спостерігались у 63,3 $\pm 1,7 \%$ опоросах, а частка мертвонароджених поросят становила 12,6 \pm 0,4\%. Частка поросят, народжених мертвими від загальної кількості поросят при народженні, отримана у иьому дослідженні, знаходиться в межах діапазону від 5 до 15\%, щуо також було відмічено для комериійних свинарських ферм в інших краӥнах. Частота гнізд, шуо мали 1, 2, 3, 4 та 5 або більше мертвонароджених поросят, становила 27,1, 14,8, 10,6, 5,8 та 5,0\%, відповідно. Частота гнізд принаймні з одним мертвонародженим поросям коливалася від 44 \% (2-й опорос) до 76 \% (6-й опорос). Суттєвим фактором при аналізі частоти гнізд принаймні з одним мертвонародженим поросям був номер опоросу свиноматки (критерій хіквадрат: $\left.\chi^{2}=51,35 ; d f=7 ; P<0,001\right)$. Ця частота зростала зі збільшенням номеру опоросу свиноматки (коефіцієнт кореляиіі Пірсона: $r=0,929 ;$; 0,01). Встановлено, щзо випадки мертвонародження поросят мали місце вже під час першого опоросу майже у половини (46\%) досліджених свиноматок ВБП. Загалом, ией розподіл добре апроксимується рівнянням експоненціальної моделі (y=73,567*exp (-0,551x); $\left.R^{2}=97,09 \%\right)$. Більшість проаналізованих свиноматок із 8-ми досліджених опоросів мали хоча б одне мертвонароджене порося у трьох-семи опоросах. Значення ентропії ознак NSB та FSB суттєво варіювали серед свиноматок залежно від номеру опоросу (критерій хі-квадрат: в обох випадках $P<0,001$ ). У той же час було відмічено значне підвищення оцінок ентропї для обох ознак від 1-го до 8-го опоросу (коефіщієнт рангової кореляції Спірмена: Р < 0,001 ... 0,002).

Ключові слова: мертвонароджені поросята, свиноматки, номер опоросу, ентропія, велика біла порода свиней.

\section{Вступ}

3 початку 1990-х років, головною метою в свинарстві стало підвищення рівня багатоплідності свиноматок для максимізації кількості отриманих поросят як при народженні, так і при відлученні на одну свиноматку за рік (Biermann et al., 2014; Kramarenko et al., 2018). Таким чином, поліпшення репродуктивних ознак свиноматок є ключовим фактором, що визначає ефективність технологічного циклу відтворення свиней і рентабельність виробництва свинини.

Багатоплідність свиноматок - комплексна ознака, яка визначається цілим набором факторів генетичної і не-генетичної природи (Kramarenko et al., 2019a). 3 останніх, вік свиноматки (тобто, номер опоросу), який визначає фізіологічний статус тварини (ріст, розвиток репродуктивної системи, кондицію і т.і.), напевно, найбільшого мірою визначає іії репродуктивні функції (Schwarz \& Kopyra, 2006; Canario et al., 2006).

Як правило, розмір гнізда свиноматок має тенденцію підвищуватися до 3-5-го опоросів, а потім плавно знижується (Tantasuparuk et al., 2000; Tummaruk et al., 2000; Lavery et al., 2019; Kramarenko et al., 2020), що пов'язано зі зростанням кількості мертвонароджених поросят у свиноматок старших вікових груп. Ця закономірність найчастіше пояснюється істотним осалюванням свиноматок або зниженням м'язового тонусу матки $з$ віком, що робить менш ефективним процес опоросу (Leenhouwers et al., 1999; Borges et al., 2005). 3 іншого боку, кількість мертвонароджених поросят збільшується при підвищенні розмірів гнізда, що пов'язано, перш за все, з асфіксією поросят під час пологів (Zaleski \& Hacker, 1993; Canario et al., 2006).

Таким чином, основною метою роботи був аналіз кількості та частки мертвонароджених поросят у гніздах свиноматок великої білої породи.

\section{Матеріал і методи досліджень}

Для аналізу було використано дані щодо відтворювальних ознак 100 свиноматок великої білої породи (ВБП), які утримувалися в умовах ТОВ “Таврійські свині” Скадовського району Херсонської області протягом 2007-2017 років. Для кожної свиноматки було проаналізовано перші вісім опоросів (Р1-P8). Таким чином, загалом, в аналіз було включено дані щодо 800 опоросів.
Для кожної свиноматки було оцінено наступні ознаки: загальна кількість поросят при народженні (TNB - total no. piglets born), кількість мертвонароджених поросят (NSB - no. of stillborn piglets) та частка мертвонароджених поросят (FSB - freq. of stillborn piglets).

Для досліджених показників нами було розраховано оцінки безумовної ентропії та ії похибки $\left(H \pm S E_{H}\right)$ за алгоритмом ентропійно-інформаційного аналізу кількісних ознак. У нашому випадку розмах значень було поділено на 10 інтервалів, що дає максимальне можливе значення ентропії Нmax = 3,322 біт.

Для порівняння індивідуальних оцінок ентропії було використано критерій Хi-квадрат Пірсона $\left(\chi^{2}\right)$, який розраховано за наступною формулою:

$$
\begin{aligned}
& \chi^{2}=\left[\sum \frac{H^{2}}{\operatorname{Var}(H)}\right]-\frac{\left[\sum \frac{H}{\operatorname{Var}(H)}\right]^{2}}{\sum \frac{1}{\operatorname{Var}(H)}}, \\
& \text { де } \operatorname{Var}(H)=S E_{H^{2}} .
\end{aligned}
$$

Отримана таким чином оцінка була порівняна із табличним значенням критерію Хі-квадрат із числом ступенів свободи $d f=k-1$, де $k$ - число груп, що порівнювалися.

Оцінку ступеня подібності часових коливань досліджених ознак протягом восьми опоросів свиноматок було проведено 3 використанням непараметричного критерію рангової кореляції Спірмена $(R s)$.

Всю статистичну обробку було проведено на підставі посібника S. Kramarenko et al. (2019b) за допомогою програмного забезпечення MS Excel та PAST (Hammer et al., 2001).

\section{Результати та їх обговорення}

При аналізі 800 опоросів (100 свиноматок ВБП, що мали по вісім опоросів) було зареєстровано народження 9037 поросят. Таким чином, середній розмір гнізда при народженні становив 11,3 поросяти. Загальна кількість мертвонароджених поросят складала 1142 особини, тобто, в середньому в одному гнізді було відмічено 1,4 \pm 0,1 поросяти, які народилися мертвими. Середня частка мертвонароджених поросят у гнізді свиноматок ВБП становила $12,6 \pm 0,4 \%$. 
За даними ряду авторів, частка мертвонароджених поросят від загальної кількості народжених поросят (тобто, розміру гнізда) коливається від 5 до $15 \%$ для комерційних свинарських ферм в різних країнах Світу (Zaleski \& Hacker, 1993; Fraser et al., 1997; Leenhouwers et al., 2001; Koketsu et al., 2010).

Таким чином, результати, отримані нами для свиноматок ВБП потрапляють у цей інтервал. Виявлено низку факторів, що пов'язані із часткою мертвонароджених поросят у гнізді. До них належать: розмір гнізда та маса гнізда при народженні, інфекційні захворювання (наприклад, парвовірус), тривалість поросності, номер опоросу, тривалість опоросу, інтервал між опоросами, дистоція, висока температура навколишнього середовища, стан свиноматки та дефіцит поживних речовин (Leenhouwers et al., 1999; Tantasuparuk et al., 2000; Lucia Jr. et al., 2002; Segura
Correa \& Solorio-Rivera, 2013). Із показників, що пов'язані із новонародженими поросятами, це: концентрація гемоглобіну в крові поросяти, порядковий номер народження під час пологів, розрив пуповини та інтервал між послідовним народженням окремих поросят (Zaleski \& Hacker, 1993).

Із 800 гнізд, що було проаналізовано, наявність мертвонароджених поросят було зафіксовано у 506 випадках, тобто, частота гнізд, що мали хоча б одне мертвонароджене порося, складає $63,3 \pm 1,7$ \%. Це значення було майже вдвічі вищим, ніж оцінка (31,3 \%), отримана для Бразилії (Borges et al., 2005).

Розподіл гнізд свиноматок ВБП за кількістю мертвонароджених поросят наведено на рис. 1А. Частота гнізд, що мали $0,1,2,3,4,5$ та більше мертвонароджених поросят складала 36,7 \%, 27,1 \%, 14,8 \%, 10,6 \%, 5,5\% та 5,0\%, відповідно.

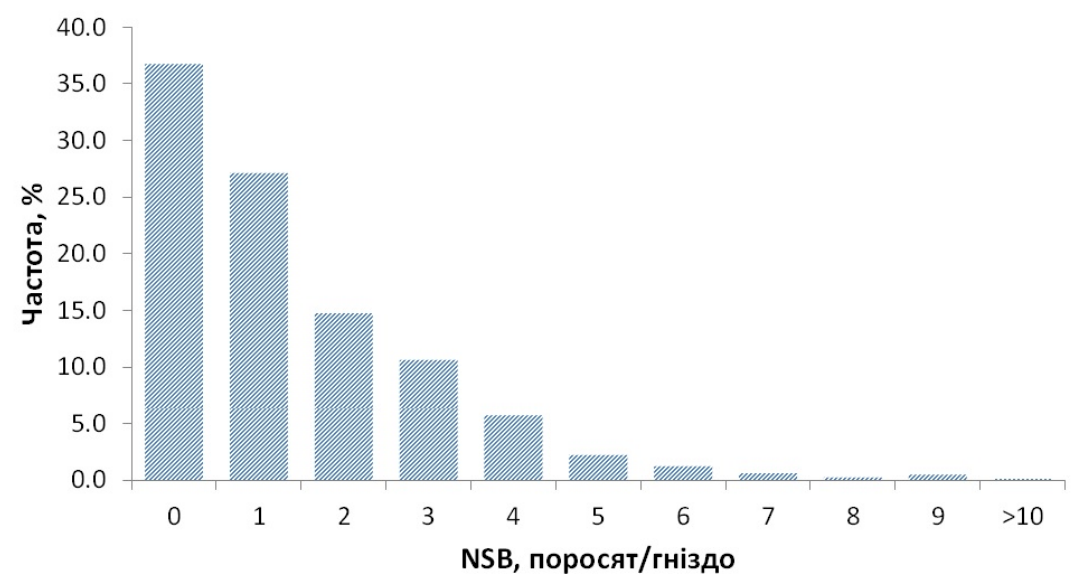

A

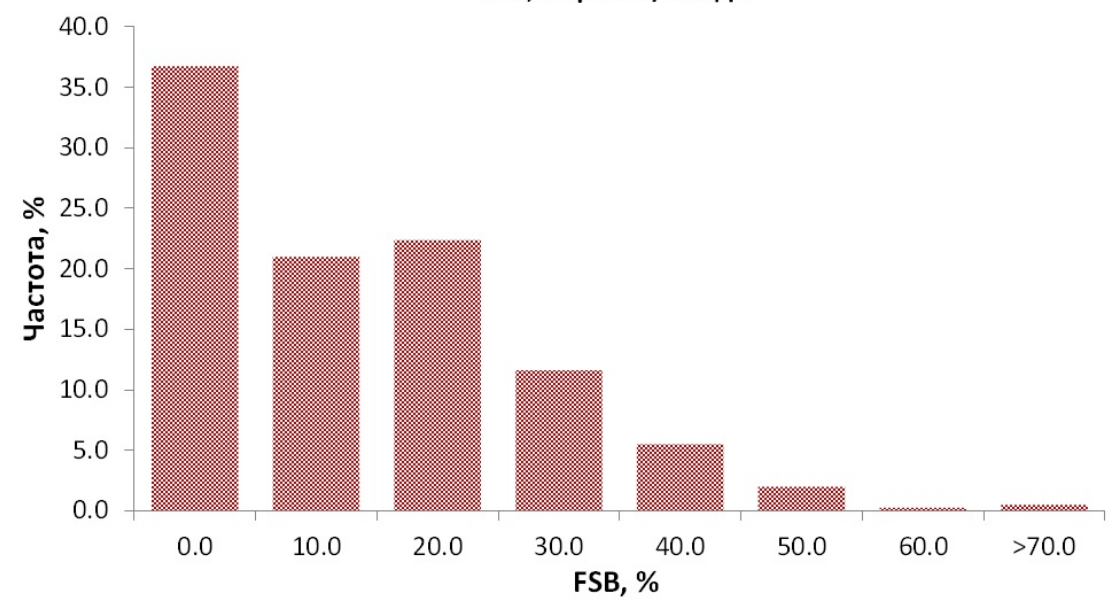

B

Рис. 1. Розподіл гнізд за кількістю (А) та часткою мертвонароджених поросят (В) у гнізді свиноматок ВБП

Розподіл гнізд свиноматок ВБП за часткою мертвонароджених поросят наведено на рис. 1Б. Серед гнізд із мертвонародженими поросятами найбільше було таких, у яких частка мертвонароджених поросят складала 1-30\%; всього було зафіксовано 440 таких гнізд (із 506, тобто, 87,0 \%).

Характерно, що частка гнізд, що мали хоча б одне мертвонароджене порося, коливалася від 44 \% (для 2- го опоросу) до $76 \%$ (для 6-го опоросу) (рис. 2). В цілому, було доведено високо вірогідний вплив номеру опоросу (тобто, віку свиноматки) на частку гнізд, в яких було зафіксовано мертвонароджених поросят (критерій Хі-квадрат: $\chi^{2}=51,35 ; d f=7 ; \mathrm{P}<0,001$ ). Більше того, має місце вірогідне збільшення цієї частки зі зростанням номеру опоросу (лінійний тренд: $r=0,929 ; \mathrm{P}<0,01$ ) (див. рис. 2). 


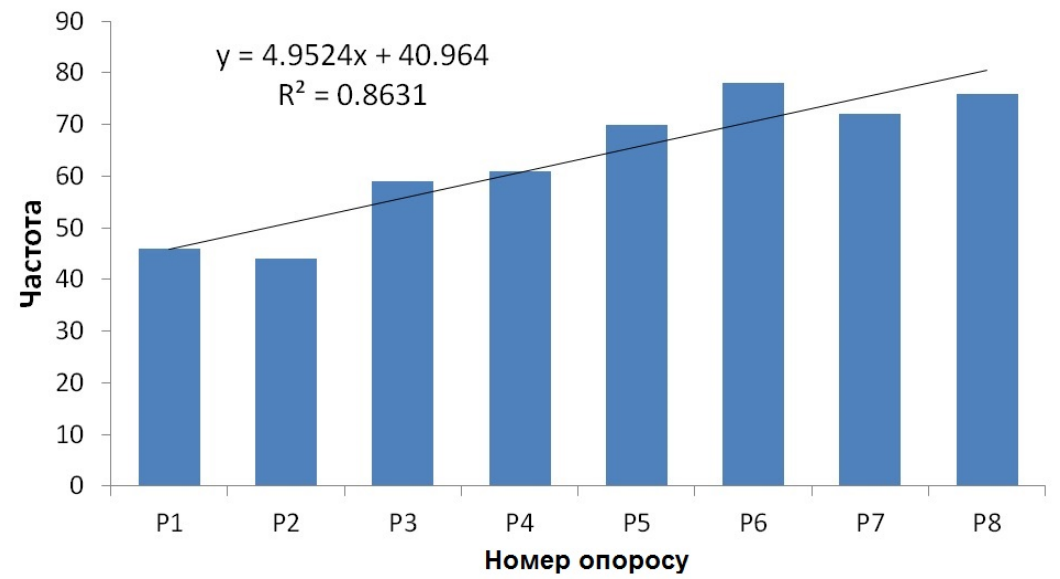

Рис. 2. Розподіл у відношенні номеру опоросу із наявністю мертвонароджених поросят у гнізді свиноматок ВБП

Більш високі шанси появи мертвонароджених поросят зі збільшенням номера опоросу узгоджуються 3 результатами інших авторів (Le Cozler et al., 2002; Borges et al., 2005; Segura Correa et al., 2007; Weber et al., 2009). Водночас, в інших дослідженнях вказується про більш високу частку мертвонароджених поросят для 1-го і 5+ опоросів у порівнянні зі свиноматками 25-го опоросів (Borges et al., 2005).

Виявлена в цьому дослідженні тенденція до зниження шансів мертвонародження при 2-му опоросі, ймовірно, пояснюється меншим розміром гнізда внаслідок т.зв. “синдрому другого гнізда” (розмір гнізда при 2-му опоросі виявляється меншим у порівнянні $з$ 1-м опоросом свиноматки) (Segura Correa \& SolorioRivera, 2013).

Якщо розглядати номер опоросу, в якому вперше в гнізді свиноматок ВБП було відмічено наявність хоча б одного мертвонародженого поросяти, то майже для половини свиноматок (46 \%) це відбулося вже під час 1-го опоросу (рис. 3). В цілому, цей розподіл добре апроксимується рівнянням експоненційної моделі із дуже високим значенням коефіцієнта детермінації $\left(R^{2}=97,09 \%\right)$. Таким чином, згідно цієї моделі під час 5-го опоросу більше $95 \%$ досліджених свиноматок вже будуть мати гнізда із мертвонародженими поросятами (див. рис. 3).

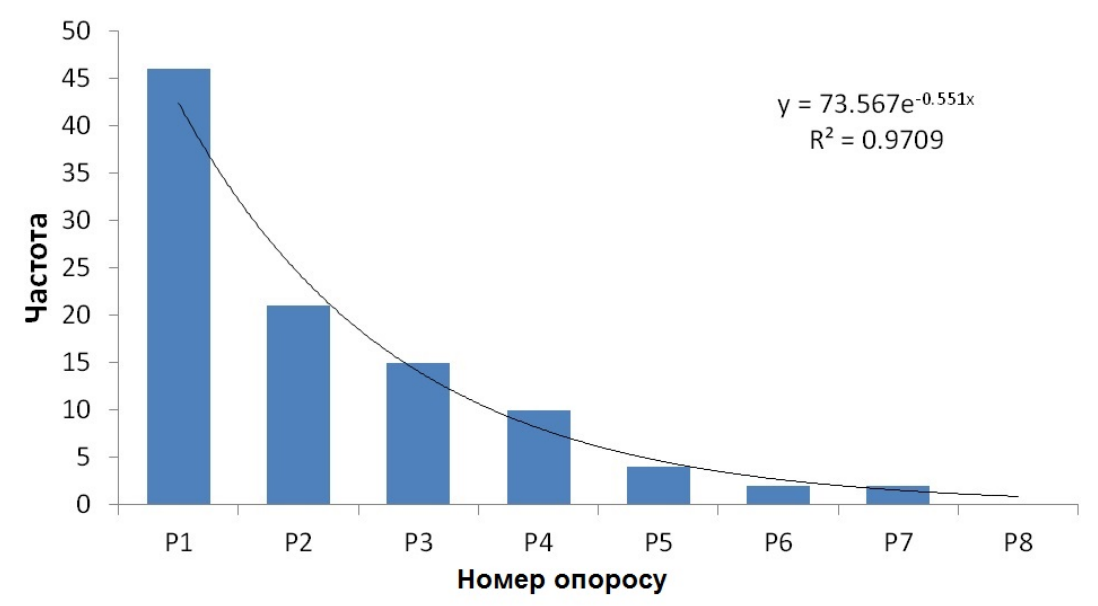

Рис. 3. Розподіл у відношенні номеру опоросу, при якому вперше було відмічено наявність мертвонароджених поросят у гнізді свиноматок ВБП

Найчастіше свиноматки мали мертвонароджених поросят у чотирьох опоросах (рис. 4). При цьому, майже 90 \% проаналізованих свиноматок із 8-ми досліджених опоросів мали хоча б одне мертвонароджене порося у трьох-семи опоросах. У цілому, цей розподіл добре апроксимується рівнянням біноміального розподілу (критерій Колмогорова-Смирнова: $d_{\mathrm{KS}}=0,099$; $\mathrm{P}>0,05)$.

Рівень організованості системи “кількість мертвонароджених поросят" та “частка мертвонароджених поросят" суттєво змінюється у свиноматок різного віку (критерій Хі-квадрат Пірсона: $\chi^{2}=459,50 ; d f=7$; P $<0,001 ; \chi^{2}=200,70 ; d f=7 ; P<0,001$, відповідно).

При цьому спостерігається вірогідне збільшення оцінок ентропії для обох показників від 1-го опоросу до 8-го (коефіцієнт рангової кореляції Спірмена: $R s=$ 0,905; $n=8 ; P=0,002 ; R s=0,952 ; n=8 ; P<0,001$, відповідно) (рис. 5). 


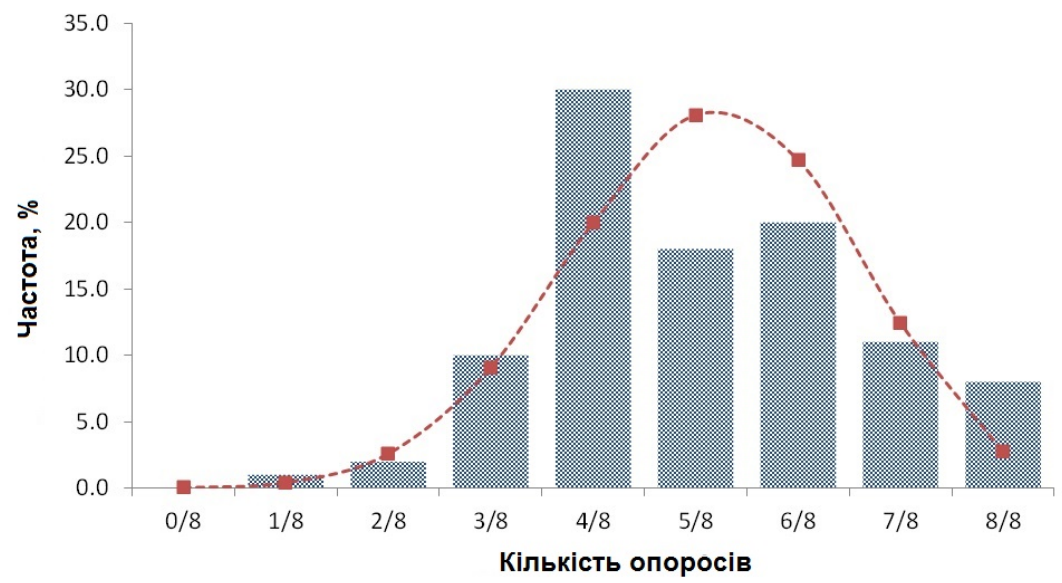

Рис. 4. Розподіл свиноматок ВБП за кількістю опоросів, в яких було зафіксовано мертвонародженість поросят.

(Наведено лінію теоретичного розподілу за біноміальною моделлю для $p=0,6375$ )

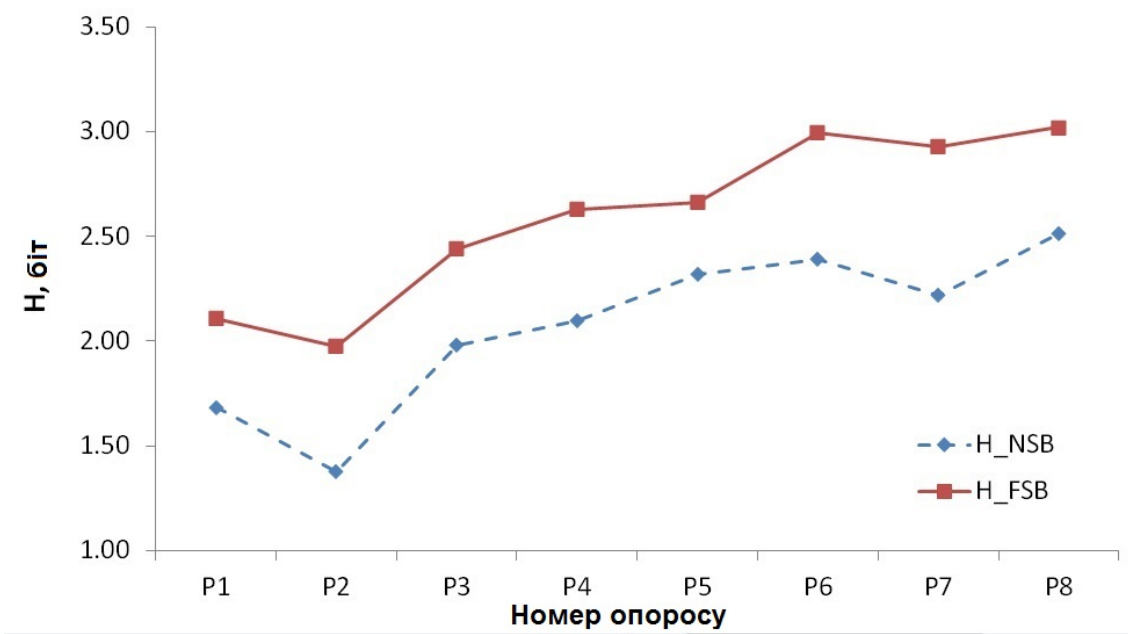

Рис. 5. Оцінки ентропії (Н) кількості та частки мертвонароджених поросят у гнізді свиноматок ВБП

Це свідчить про те, що у повновікових свиноматок на кількість (та частку) мертвонароджених поросят в гнізді впливає багато факторів, які, однак, є відносно слабкими. Водночас, у першоопоросок, навпаки, ця ознака знаходиться під значним контролем.

Частково це може бути пояснено тим фактом, що свиноматки під час пізніших опоросів зазвичай народжують більш численні гнізда (Lucia Jr. et al., 2002). Крім того, цей зв'язок може бути пов'язаний 3 надмірним ожирінням (Canario et al., 2006) та/або поганим тонусом м'язів матки, що може призвести до менш ефективних пологів та більш тривалого процесу опоросу у свиноматок старшого віку (Lucia Jr. et al., 2002; Canario et al., 2006). Крім того, мертвонароджені поросята частіше зустрічалися при більш тривалих опоpocax. Ймовірно, це зумовлено тим, що в таких випадках розміри гнізд були відносно більшими, а інтервалами між народженням окремих поросят - подовженими, що перевищували 60 хвилин (Fraser et al., 1997).

\section{Висновки}

Середній розмір гнізда при народженні складав 11,3 поросяти на гніздо. В середньому в одному гнізді було відмічено $1,4 \pm 0,1$ поросят, які були народжені мертвими. Середня частка мертвонароджених поросят у гнізді свиноматок ВБП складала $12,6 \pm 0,4 \%$. Частка гнізд, в яких було хоча б одне мертвонароджене порося, коливалася від $44 \%$ (для 2-го опоросу) до $76 \%$ (для 6-го опоросу). В цілому, було доведено високо вірогідний вплив номеру опоросу (тобто, віку свиноматки) на частку гнізд, в яких було зафіксовано мертвонароджених поросят. При цьому, має місце вірогідне збільшення цієї частки із зростанням номеру опоросу.

Нами було відмічено, що майже для половини свиноматок (46 \%) поява у гнізді хоча б одного мертвонародженого поросяти відбулася вже під час 1-го опоросу. В цілому, цей розподіл добре апроксимується рівнянням експоненційної моделі. Майже $90 \%$ проаналізованих свиноматок із 8-ми досліджених опоросів мали хоча б одне мертвонароджене порося у трьох-семи опоросах.

Рівень організованості системи «кількість мертвонароджених поросят» та «частка мертвонароджених поросят» суттєво змінюється серед свиноматок різного віку. При цьому спостерігається вірогідне збільшення оцінок ентропії для обох показників від 1-го до 8-го опоросу.

Перспективи подальших досліджень. Подальші дослідження повинні бути спрямовані на аналіз гене- 
тичних та не-генетичних факторів, що впливають на кількість та частку мертвонароджених поросят у гніздах свиноматок ВБП із побудовою відповідних математичних моделей.

Подяки. Робота виконана в рамках фінансування за держбюджетними тематиками Міністерства освіти і науки України (номера державної реєстрації 0119U001042 та 0121U109492).

\section{References}

Biermann, A. D. M., Pimentel, E. C. G., Tietze, M., Pinent, T., \& König, S. (2014). Implementation of genetic evaluation and mating designs for the endangered local pig breed 'Bunte Bentheimer'. Journal of Animal Breeding and Genetics, 131(1), 36-45. doi: 10.1111/jbg.12041.

Borges, V. F., Bernardi, M. L., Bortolozzo, F. P., \& Wentz, I. (2005). Risk factors for stillbirth and foetal mummification in four Brazilian swine herds. Preventive Veterinary Medicine, 70(3-4), 165-176. doi: 10.1016/j.prevetmed.2005.03.003.

Canario, L., Cantoni, E., Le Bihan, E., Caritez, J.C., Billon, Y., Bidanel, J.P., \& Foulley, J.L. (2006). Betweenbreed variability of stillbirth and its relationship with sow and piglet characteristics. Journal of Animal Science, 84(12), 3185-3196. doi: 10.2527/jas.2005-775.

Fraser, D., Phillips, P. A., \& Thompson, B. K. (1997). Farrowing behaviour and stillbirth in two environments: an evaluation of the restraint-stillbirth hypothesis. Applied Animal Behaviour Science, 55(1-2), 5166. doi: 10.1016/S0168-1591(97)00007-5.

Hammer, O., Harper, D. A., \& Ryan, P. D. (2001). PAST: Paleontological Statistics Software Package for Education and Data Analysis. Palaeontologia Electronica, 4, 1-9. URL: http://palaeoelectronica.org/2001 1/past/issue1 01.htm.

Koketsu, Y., Sasaki, Y., Ichikawa, $\bar{H}$., \& Kaneko, M. (2010). Benchmarking in animal agriculture: concepts and applications. Journal of Veterinary Epidemiology, 14(2), 105-117. doi: 10.2743/jve.14.105.

Kramarenko, A. S., Ignatenko, Zh. V., Lugovoy, S. I., Pidpala, T. V., Karatieieva, O. I., Yulevich, O. I., Artyuhova, O. V., \& Kramarenko, S. S. (2020). Effect of parity number, year and season farrowing on reproductive performance in Large White pigs. Ukrainian Journal of Ecology, 10(1), 307-312. doi: 10.15421/2020 48.

Kramarenko, S., Lugovoy, S., Lykhach, A., Kramarenko, A., \& Lykhach, V. (2018). A comparative study of the reproductive traits and clustering analysis among different pig breeds. Scientific Messenger of LNU of Veterinary Medicine and Biotechnologies. Series: Agricultural Sciences, 20(84), 21-26. doi: 10.15421/nvlvet8404.

Kramarenko, S., Lugovoy, S., Lykhach, A., Kramarenko, A., Lykhach, V., \& Slobodianyk, A. (2019a). Effect of genetic and non-genetic factors on the reproduction traits in Ukrainian Meat sows. Scientific Messenger of LNU of Veterinary Medicine and Biotechnologies. Series: Agricultural Sciences, 21(90), 3-8. doi: 10.32718/nvlvet-a9001.

Kramarenko, S. S., Lugovy, S. I., Lykhach, A. V., \& Kramarenko, O. S. (2019b). Analysis of biometric da- ta in animal breeding and selection. Mykolayiv, MNAU (in Ukrainian).

Lavery, A., Lawlor, P. G., Magowan, E., Miller, H. M., O’Driscoll, K., \& Berry, D. P. (2019). An association analysis of sow parity, live-weight and back-fat depth as indicators of sow productivity. Animal, 13(3), 622630. doi: 10.1017/S1751731118001799.

Le Cozler, Y., Guyomarc'h, C., Pichodo, X., Quinio, P. Y., \& Pellois, H. (2002). Factors associated with stillborn and mummified piglets in high-prolific sows. Animal Research, 51(3), 261-268. doi: 10.1051/animres:2002017.

Leenhouwers, J. I., van der Lende, T., \& Knol, E. F. (1999). Analysis of stillbirth in different lines of pig. Livestock Production Science, 57(3), 243-253. doi: 10.1016/S0301-6226(98)00171-7.

Leenhouwers, J. I., de Almeida Junior, C. A., Knol, E. F., \& Van der Lende, T. (2001). Progress of farrowing and early postnatal pig behavior in relation to genetic merit for pig survival. Journal of Animal Science, 79(6), 1416-1422. doi: 10.2527/2001.7961416x.

Lucia Jr., T., Corrêa, M. N., Deschamps, J. C., Bianchi, I., Donin, M. A., Machado, A. C., Meincke, W., \& Matheus, J. E. (2002). Risk factors for stillbirths in two swine farms in the south of Brazil. Preventive veterinary medicine, 53(4), 285-292. doi: 10.1016/S0167-5877(01)00288-4.

Schwarz, T., \& Kopyra, M. (2006). Influence of age on insemination process, and reproductive performance in sows. Animal Science Papers and Reports, 24 (suppl. 3), 229-239.

Segura Correa, J. C., Alzina-López, A., \& Rivera, J. L. S. (2007). Evaluación de tres modelos y factores de riesgo asociados a la mortalidad de lechones al nacimiento en el trópico de México. Técnica pecuaria en México, 45(2), 227-236. URL: https://dialnet.unirioja.es/ servlet/articulo? codigo $=2310503$.

Segura Correa, J. C., \& Solorio-Rivera, J. L. (2013). Risk factors for stillborn pigs and mummified fetuses in two swine farms in southeastern Mexico. Livestock Research for Rural Development, 25 (Article \#173). URL: http://www.lrrd.org/lrrd25/10/solo25173.htm.

Tantasuparuk, W., Lundeheim, N., Dalin, A. M., Kunavongkrit, A., \& Einarsson, S. (2000). Reproductive performance of purebred Landrase and Yorkshire sows in Thailand with special reference to seasonal influence and parity number. Theriogenology, 54(3), 481-496. doi: 10.1016/S0093-691X(00)00364-2.

Tummaruk, P., Lundeheim, N., Einarsson, S., \& Dalin, A. M. (2000). Reproductive performance of purebred Swedish Landrace and Swedish Yorkshire sows: I. Seasonal variation and parity influence. Acta Agriculturae Scandinavica Section A - Animal Science, 50, 205-216. doi: 10.1080/090647000750014331.

Weber, R., Keil, N. M., Fehr, M., \& Horat, R. (2009). Factors affecting piglet mortality in loose farrowing systems on commercial farms. Livestock Science, 124(1-3), 216-222. doi: 10.1016/j.livsci.2009.02.002.

Zaleski, H. M., \& Hacker, R. R. (1993). Effect of oxygen and neostigmine on stillbirth and pig viability. Journal of animal science, 71(2), 298-305. doi: $10.2527 / 1993.712298 x$. 